\title{
Effect of Flaky Plastic Particle Size and Volume Used as Partial Replacement of Gravel on Compressive Strength and Density of Concrete Mix
}

\author{
Stanley O. Osubor1 ${ }^{1}$, Kamoru A. Salam ${ }^{*}$, Taiwo M. Audu² \\ ${ }^{1}$ Department of Chemical Engineering, Faculty of Engineering, University of Abuja, Abuja, Nigeria \\ ${ }^{2}$ Department of Civil Engineering, Faculty of Engineering, University of Abuja, Abuja, Nigeria \\ Email: ^kamorusalam@gmail.com
}

How to cite this paper: Osubor, S.O., Salam, K.A. and Audu, T.M. (2019) Effect of Flaky Plastic Particle Size and Volume Used as Partial Replacement of Gravel on Compressive Strength and Density of Concrete Mix. Journal of Environmental Protection, 10, 711-721.

https://doi.org/10.4236/jep.2019.106042

Received: April 16, 2019

Accepted: May 27, 2019

Published: May 30, 2019

Copyright $\odot 2019$ by author(s) and Scientific Research Publishing Inc. This work is licensed under the Creative Commons Attribution International License (CC BY 4.0).

http://creativecommons.org/licenses/by/4.0/

\begin{abstract}
Common ways of disposing waste plastic such as incineration and landfilling have negative impacts on the environment. Partial replacement of natural aggregate in concrete with waste plastic including polyethylene terephthalate (PET) is more environmental friendly and sustainable. The effect of adding $5 \%$ to $20 \%$ waste plastic by volume of natural coarse aggregate ("gravel") and plastic particle size ( 3 to $7 \mathrm{~mm}$ ) on the density and compressive strength of plastic-concrete mix after 28 days of curing was studied. The results showed that density of the concrete decreased from 2406.7 to $2286.7 \mathrm{~kg} / \mathrm{m}^{3}$ as waste plastic increased from $5 \%$ to $20 \% \mathrm{v} / \mathrm{v}$ compared with $2443.3 \mathrm{~kg} / \mathrm{m}^{3}$ recorded by concrete without waste plastic. Change in particle size from 3 to $7 \mathrm{~mm}$ has no significant effect on the density of the plastic-concrete mix. The compressive strength decreased as the volume and particle size of waste plastic increased. When waste plastic volume changed from $5 \%$ to $20 \% \mathrm{v} / \mathrm{v}$, the compressive strength decreased from 20.5 to $15 \mathrm{MPa}, 18.6$ to $14.3 \mathrm{MPa}$ and 17.2 to $13.8 \mathrm{MPa}$ for 3, 5 and $7 \mathrm{~mm}$ waste plastic particle size respectively while the concrete without plastic has $21.33 \mathrm{MPa}$. Therefore, the addition of $5 \%$ ( $\mathrm{v} / \mathrm{v}$ gravel) of flaky waste plastic in the concrete produces a lightweight concrete which could offer economic benefit without substantially reducing the compressive strength of the plastic-concrete mix.
\end{abstract}

\section{Keywords}

Flaky Plastic, Compressive Strength, Density, Gravel, Particle Size, Plastic-Concrete Mix 


\section{Introduction}

Plastic is commonly produced from petroleum-based materials which are nonrenewable. Urbanization and rapid global industrial growth have increased usage of plastic materials in our daily needs [1]. For instance, plastic is applicable in making polythene bags, food packaging materials, water bottles, containers, cutting boards, electrical appliances, furniture, vehicles, plastic beverage, margarine, shampoo and detergent bottles [2]. The world's annual consumption of plastic products was about 5 million tons in the 1950s which has now increased to 100 million tons, resulting in increase in generation of plastic waste [3].

Plastic waste materials include surplus, obsolete, broken, old plastic furniture, different household plastic materials, equipment, anti-static packaging materials and devices containing plastic. Waste polyethylene terephthalate (PET) bottles can contaminate natural water streams, killing aquatic animals and can clog up urban drainage systems resulting in urban floods if they are not properly addressed [4]. These waste plastics are naturally non-degradable even after a long period [5] due to their high thermal, mechanical and chemical resistance. Similarly, incineration of plastic waste produces secondary pollutants such as toxic gases and carbon monoxide. Hence, landfilling and incineration of waste plastic is non-attractive option. Those common ways of disposing plastics significantly contribute to accumulation of waste plastic and emission of air pollutants in the environment [6] [7].

A more appealing and sustainable way of disposing plastic is to include it in another product [8]. For instance waste plastic can be used as partial replacement of natural aggregate such as gravel and sand in concrete. This study evaluates the use of flaky PET waste plastics of three different sizes as partial replacement of natural coarse aggregate ("gravel") in concrete. Specifically the effect of replacing gravel in concrete with different volume and size of flaky PET on compressive and density of PET-concrete mix was studied. Very limited studies are available in this area.

\section{Methodology}

\subsection{Materials}

Dangote Portland Cement used was supplied by a cement merchant in Samaru, Ahmadu Bello University, Zaria, Nigeria. Its grade was 42.5 which conform to the standard recommended by CEM II A-L BS EN 197-1 [9]. River dredged-air-dried, sharp sand of particle size $(1.0-1.05 \mathrm{~mm})$ and gravel of particle size $(10-17 \mathrm{~mm})$ were both obtained from the same locality in Samaru, Zaria, Nigeria. Moisture content of the sand and gravel were $0.4 \%$ and $0.6 \%$ respectively. The water absorption capacity of the sand and gravel were $2 \%$ and $1.2 \%$ respectively. The aggregates' quality conforms to BS EN 12620:2002 + A1 [10].

Clean tap water obtained within the Department of Building, Ahmadu Bello University, Samaru, Zaria, Kaduna state, was used in mixing concrete constitu- 
ents. The flaky polyethylene terephthalate (PET) plastics of three different sizes $(3,5$, and $7 \mathrm{~mm})$ were obtained from waste plastic processor and its density was $390 \mathrm{~kg} / \mathrm{m}^{3}$. A 0.6 water $/$ cement $(\mathrm{kg} / \mathrm{kg})$ was added for mixing.

\subsection{Experimental Procedures}

The control concrete (normal concrete) contains cement, sand, gravel and water while the recycled plastic aggregate concrete (RPAC) was casted by replacing percentage volume of gravel with specified quantities and size of flaked polyethylene terephthalate (PET) plastics. Firstly, three different flake sizes: (3, 5 and 7 $\mathrm{mm}$ ) of waste polyethylene terephthalate plastics were procured, and the density of each was determined to ensure homogeneity in density of the three PET sizes. Then, the moisture content and water absorption capacity of the sand and gravel were both determined via oven-dry method.

\subsection{Batching and Mixing}

The concrete mix was designed in accordance with BS 8500-2 [11]. The control concrete mix which contained no PET was made by mixing 1:2:4 of cement: sand: gravel on mass basis. In the batches compared to the control, gravel was partially replaced by PET ( $5 \%-20 \%$ v/v gravel). Then, a 0.6 water/cement $(\mathrm{kg} / \mathrm{kg})$ was added for mixing. Electric powered rotary concrete mixer was used in each batch to ensure uniform mixing.

\section{Materials Required for Casting a Batch}

A batch contains three specimens (units). For an equal volume of PET and gravel, mass of PET was measured to be $\approx 1 / 4 \times$ mass of gravel due their difference in density. Water absorption capacity of the sand used was measured as $2.0 \%(\mathrm{~kg} / \mathrm{kg}$ sand) while that of gravel was $1.2 \%(\mathrm{~kg} / \mathrm{kg}$ gravel). Table 1 shows the amount of materials required for a batch mix which was sufficient to cast 3 units of specimens (100 mm cube each). It contained 1:2:4 of cement: sand: gravel on mass basis. A 0.6 water/cement $(\mathrm{kg} / \mathrm{kg})$ was used for mixing each $5 \%$, $10 \%, 15 \%$, and $20 \%$ PET (v/v gravel). It also shows the mass ( $\mathrm{kg}$ ) equivalent to $\%$ (v/v gravel) replaced by PET.

Table 1. Materials required for casting a batch at specific gravel-PET replacement.

\begin{tabular}{ccccc}
\hline Material & $5 \%$ & $10 \%$ & $15 \%$ & $20 \%$ \\
\hline Cement (kg) & 8.357 & 8.357 & 8.357 & 8.357 \\
Sand (kg) & 16.714 & 16.714 & 16.714 & 16.714 \\
Water for sand saturation (kg) & 0.334 & 0.334 & 0.334 & 0.334 \\
Gravel (kg) & 31.758 & 30.086 & 28.415 & 26.743 \\
Water for gravel saturation (kg) & 0.381 & 0.361 & 0.341 & 0.321 \\
Water for mixing (kg) & 5.0142 & 5.0142 & 5.0142 & 5.0142 \\
\hline
\end{tabular}




\subsection{Preparation of Specimens}

After mixing the constituents of the concrete, the workability of each fresh batch was determined via slum test according to ASTM C143 [12]. A mold that has conical frustum of top and base diameter and height of 4,8 and 12 inches respectively was filled up with freshly prepared concrete mix in three layers of equal volume. Each layer was compacted with twenty-five strokes of tamping rod. Then the slump frustum mold was lifted vertically upward, and the difference between the height of the frustum and that of concrete after removing the slump frustum was measured and recorded as the slump. Throughout the tests, true slump ranged from 7 to $8.5 \mathrm{~mm}$ was observed in the various concrete mixes. After slump determination, three cube molds of the same size $(100 \mathrm{~mm})$ were filled up with fresh concrete mix. The concrete inside the mold was vibrated via electronic poker vibrator for 15 seconds to ensure uniform compaction. Then the surface of the concrete mix was leveled with trowel, and allowed to dry at $25^{\circ} \mathrm{C}$ for $24 \mathrm{~h}$. The dried concrete mix was demolded and allowed to cure in a curing tank for 28days to prevent moisture loss, and increase hardening.

\subsection{Compressive Strength Test on Hardened Concrete}

After 28 days of curing, the compressive strengths of the $100 \mathrm{~mm}$ cube concrete casts were determined for each specimen containing gravel replaced by PET $(0 \%, 5 \%, 10 \%, 15 \%$, and $20 \% \mathrm{v} / \mathrm{v}$ gravel) according to BS EN 12390-4 [13]. The hardened concrete cube specimen was placed in turn on the compression testing machine for crushing. Each hardened cube concrete was loaded steadily by the compression testing machine without shock until no more loads can be sustained. The Maximum force at each failure point was recorded from the visual display unit (VDU) of the compression machine. The compressive strength was computed using:

$$
C=\bar{P} / A
$$

where:

$C=$ Compressive strength $\left(\mathrm{MPa}\right.$ or $\left.\mathrm{N} / \mathrm{mm}^{2}\right)$.

$\bar{P}=$ Average crushing force of the three cube specimens recorded by the machine $(\mathrm{kN})$.

$A=$ Cross sectional area of the cube on which compressive force acts.

The procedure was repeated to obtain average crushing force, and the various results recorded on different PET-sizes: 3, 5 and $7 \mathrm{~mm}$.

\subsection{Determination of Density}

Densities of the cured dry concrete mix (i.e. after 28 days curing) were determined as follows. A dry cloth was used to dry off water from the wet surface of the specimen. Then, the specimen was weighed on a weighing balance and the mass recorded. The density was computed using:

$$
\text { Density, } \rho=\frac{M}{V},\left(\mathrm{~kg} / \mathrm{m}^{3}\right)
$$


where:

$M=$ mass recorded on the weighing balance $(\mathrm{kg})$;

$V=$ volume of the mold $\left(\mathrm{m}^{3}\right)$.

The procedure was used for each cube concrete mix containing PET $(0,5,10$, 15 , and $20 \% \mathrm{v} / \mathrm{v}$ gravel) for flaky plastic particle size of 3,5 , and $7 \mathrm{~mm}$.

\subsection{Statistical Analysis}

An independent sample t-test was conducted to determine if there is no significant difference (i.e. $\mathrm{p}>0.05$ ) between the mean compressive strength of the concrete that contained 5\%,10\%,15\% and 20\% PET (v/v gravel), 3, 5 and $7 \mathrm{~mm}$ PET particle size and the mean compressive strength of the concrete that contained no PET.

\section{Results and Discussion}

\subsection{Effect of Plastic Particle Size and Volume on Compressive Strength of PET-Concrete}

Figure 1 shows that increase in volume of flaky plastic from $0 \%$ to $20 \% \mathrm{v} / \mathrm{v}$ natural coarse aggregate (gravel) caused decrease in compressive strength from 21.332 to 14.971 MPa for a fixed $3 \mathrm{~mm}$ flaky plastic size.

Figure 2 shows that increase in volume of flaky plastic from $0 \%$ to $20 \% \mathrm{v} / \mathrm{v}$ natural coarse aggregate (gravel) caused decrease in compressive strength from 21.332 to $14.305 \mathrm{MPa}$ for a fixed $5 \mathrm{~mm}$ flaky plastic size.

Figure 3 shows that increase in volume of flaky plastic from $0 \%$ to $20 \% \mathrm{v} / \mathrm{v}$ natural coarse aggregate (gravel) caused decrease in compressive strength from 21.332 to $13.74 \mathrm{MPa}$ for a fixed $7 \mathrm{~mm}$ flaky plastic size.

These results clearly show that increased addition of flaky plastic in the range of $5 \%$ to $20 \% \mathrm{v} / \mathrm{v}$ of coarse aggregate consistently decreased the compressive strength regardless of the waste plastic particle size. This observed reduction in

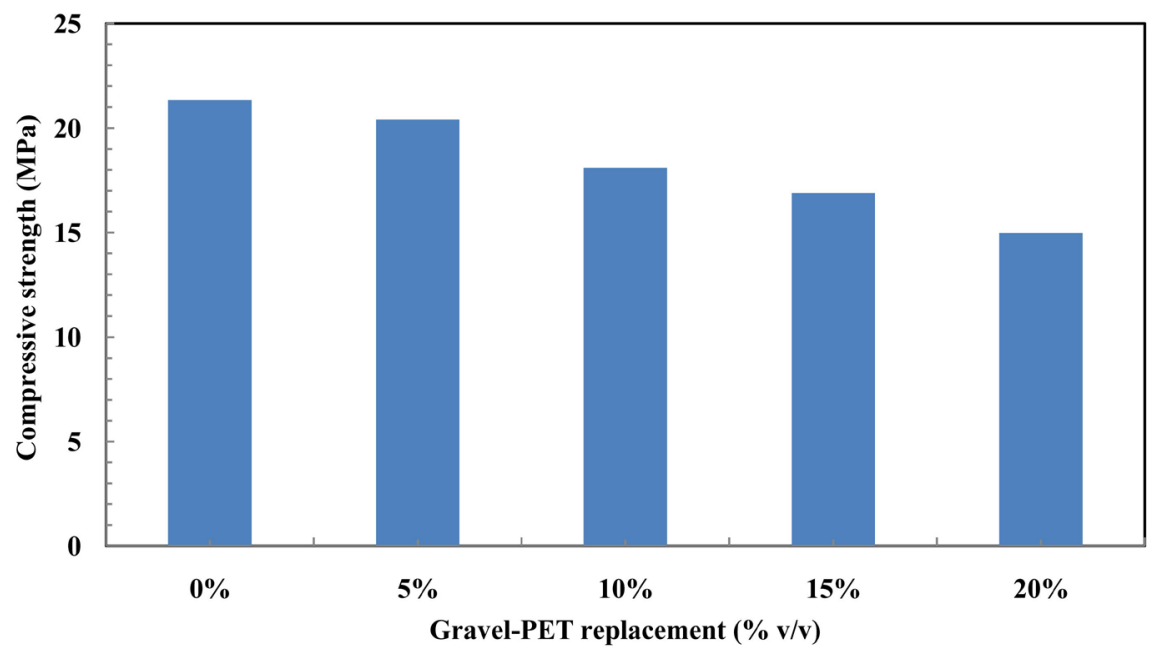

Figure 1. Change in compressive strength of PET-concrete at different PET replacement. Volume of PET added: $0 \%-20 \% \mathrm{v} / \mathrm{v}$ gravel; PET size: $3 \mathrm{~mm}$. 


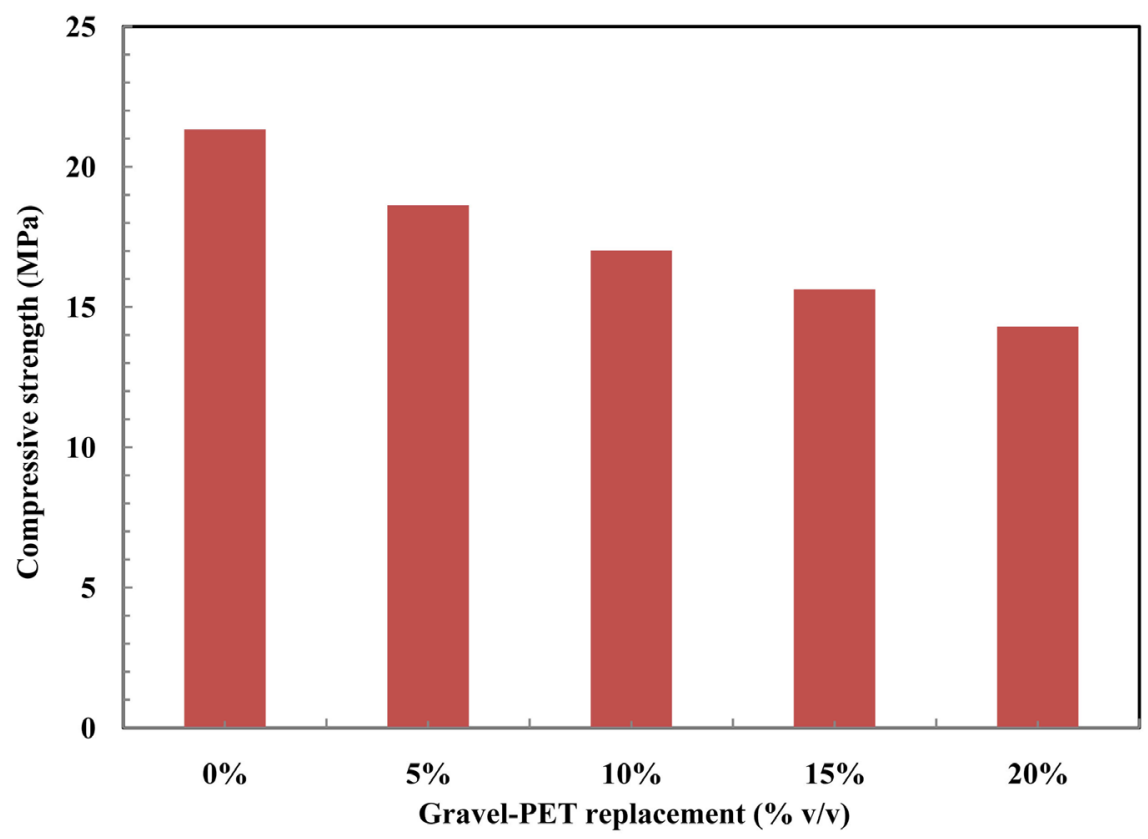

Figure 2. Change in compressive strength of PET-concrete at different PET replacement. Volume of PET added: $0 \%$ - 20\% v/v gravel; PET size: $5 \mathrm{~mm}$.

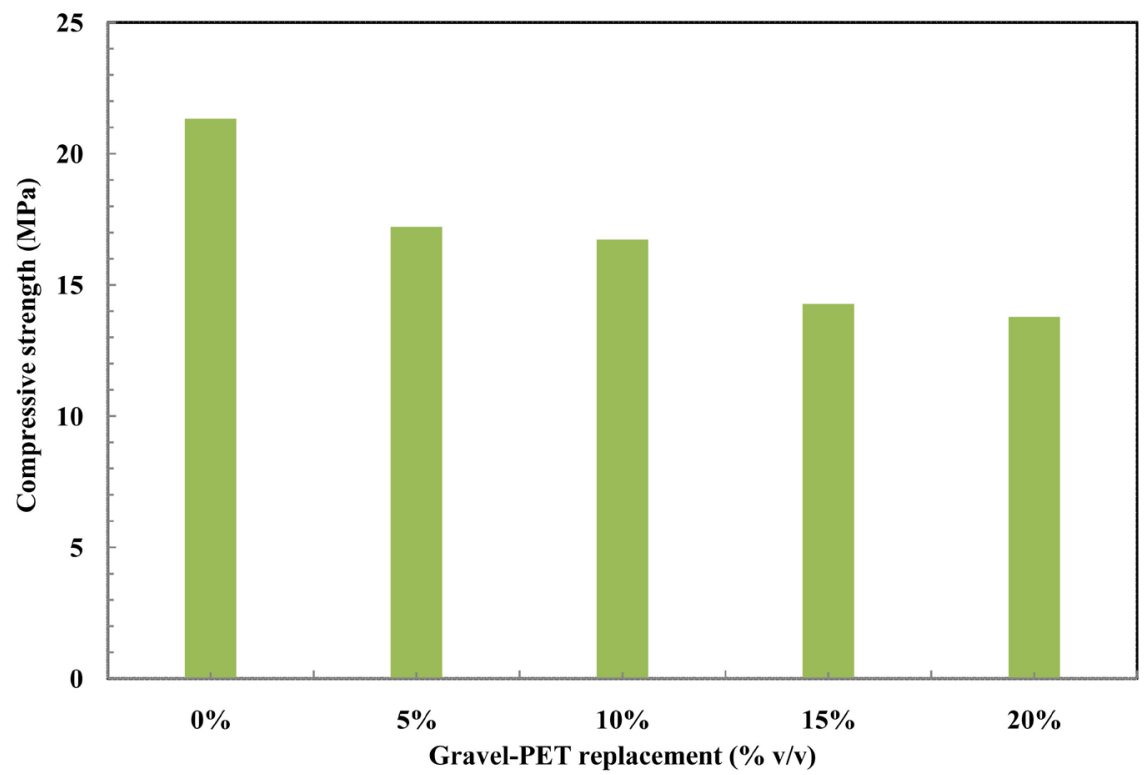

Figure 3. Change in compressive strength of PET-concrete at different PET replacement. Volume of PET added: $0 \%-20 \% \mathrm{v} / \mathrm{v}$ gravel; PET size: $7 \mathrm{~mm}$.

compressive strength is attributable to the fact that, PET aggregates unlike natural coarse aggregates, cannot bond strongly with cement as natural aggregate [14] [15]. This explains why PET-concrete mix often leaves voids within the matrix of the specimen [16] [17] [18] [19]. In addition, PET aggregates are hydrophobic i.e. cannot absorb water; hence reducing water intake necessary for cement hydration for PET concrete specimens during the curing period [20].

Generally the compressive strengths of all the PET-concrete mix regardless of 
the particle sizes were lower than the concrete without any plastic waste. These results support the findings of previous studies that increase in amount of waste plastic (PET) as aggregate in concrete reduces its compressive strength [5] [7] [21] [22] [23] [24].

In several studies the volume of natural aggregates replaced by plastic waste in concrete is usually greater than $10 \%$. For instance, Ramesh et al. [25] replaced $20 \%$ to $40 \%$ gravel by low density polyethylene (LDPE). Ismail et al. [14] replaced $10 \%$ to $20 \%$ sand by recycled plastic. Suganthy et al. [1] replaced $25 \%$ to $100 \%$ sand by plastic while Patil et al. [26] replaced $10 \%$ to $50 \%$ gravel by recycled plastic. They all observed reduction in compressive strength of the resulting plastic concrete mix. In the present study lower level was included i.e. $5 \%$ to $20 \%$ $\mathrm{v} / \mathrm{v}$ of gravel replaced by PET. This is to allow production of light weight concrete but still maintain the desired high compressive strength.

Figure 4 shows that the reduction in compressive strength due to inclusion of flaky plastic waste became more intense with increase in particle size with the highest strength at 5\% and lowest at $20 \%$ v/v gravel PET replacement. For instance at $5 \%$ inclusion, the compressive strength was $20.414,18.620$ and 17.215 MPa for 3, 5 and $7 \mathrm{~mm}$ flaky particle size respectively while at $20 \%$, the recorded compressive strength were $14.971,14.305$ and $13.78 \mathrm{MPa}$ for 3,5 and $7 \mathrm{~mm}$ flaky particle size respectively. The results obtained clearly show that both increase in percentage PET addition and size contribute to reduction in compressive strength.

Figure 5 shows the percentage reduction in compressive strength of waste plastic (PET) concrete mix compared with concrete containing no waste plastic. It shows clearly that for the $5 \%-20 \%$ PET added, the reduction in initial concrete strength range from $4.3 \%$ to $35.5 \%$ with $3 \mathrm{~mm}$ and $5 \%$ flaky plastic showing the least while $7 \mathrm{~mm}$ and $20 \%$ flaky plastic having the highest reduction in compressive strength. These reductions conform with the range reported by other researchers [24] [26] [27] [28].

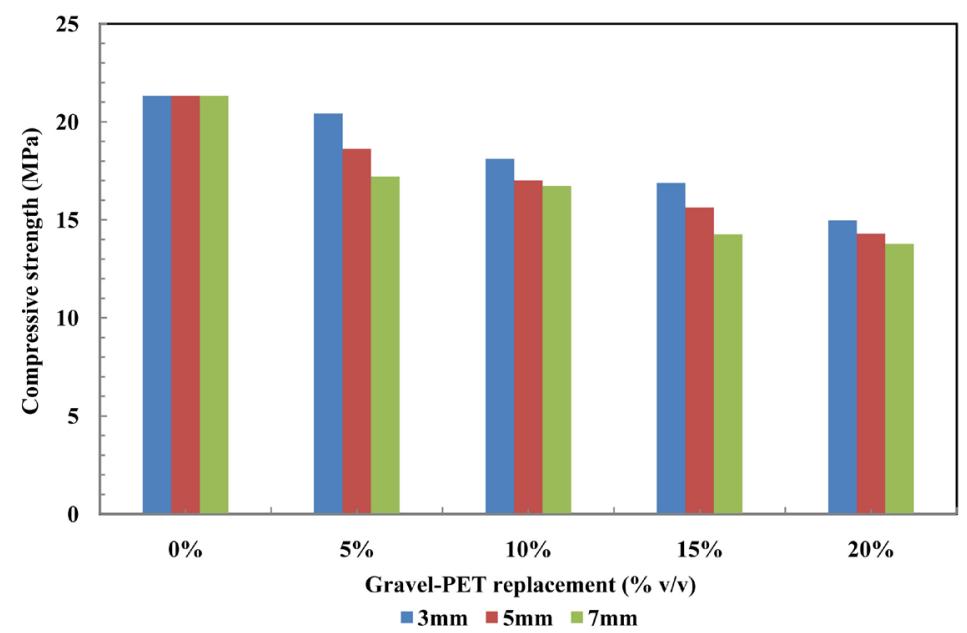

Figure 4. Change in compressive strength of PET-concrete at different volume and size of PET replacement. Volume of PET added: $0 \%$ - 20\% v/v gravel; PET size: 3 - $7 \mathrm{~mm}$. 


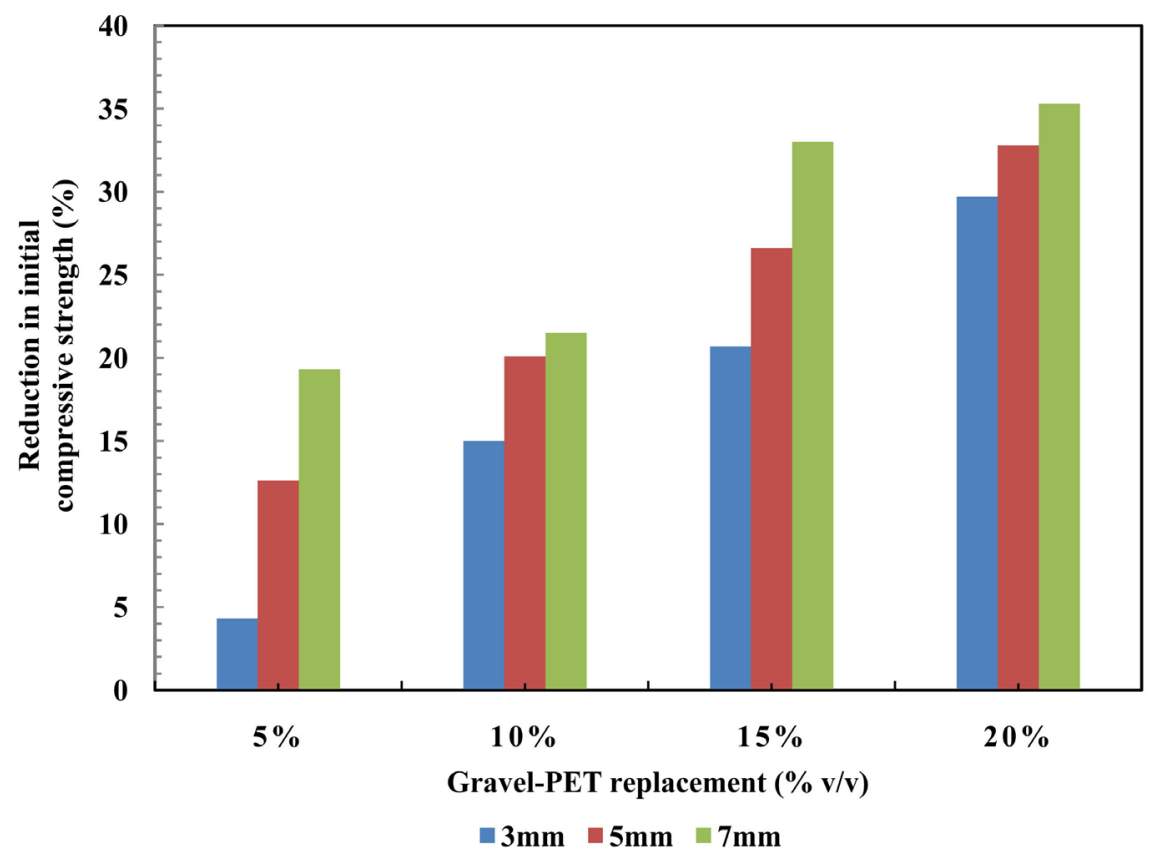

Figure 5. Percentage reduction in initial compressive strength with different gravel PET replacement. Particle size: 3 - $7 \mathrm{~mm}$; volume of PET added: 5\% - 20\% v/v gravel.

This means that reduction in compressive strength of RPACs is also influenced by size of the plastic in the mix, i.e. the bigger the size (surface area of unit particles of the plastic), the higher the reduction in compressive strength. This is because plastics surfaces have relatively poor interaction (extremely low adhesive bond) with cement paste at these surfaces. Thus, at the surface of PET-cement interface, there are always "void" caused by the poor adhesion between them. Therefore, the bigger the PET size, the greater the "void", hence the weaker the compressive strength. In other word bigger particle size often caused lower bond strength at the interfacial transition zone (ITZ) between the surface of the RPA and the cement paste.

These results conform to similar studies. Specifically, Saikia and De Brito [15] studied compressive strength of concrete mix containing three different sizes and shaped particles: 1) Large particles (10 - $20 \mathrm{~mm}$ length); 2) shredded flaky fine particles (2 - $5 \mathrm{~mm}$ length); and 3) cylindrical pellet shaped particles ( $3 \mathrm{~mm}$ length). Each of these was tested over a series of replacement ratios, ranging from $0 \%$ to $15 \%$ of fine aggregate. They found that $5 \%$ sand replacement with fine plastic aggregate caused less than $2 \%$ reduction in compressive strength. In contrast, replacement of sand with $5 \%$ larger plastic pellets caused $12 \%$ compressive strength reduction.

In the present study natural coarse aggregate (gravel) was replaced with varied size ( 3 to $7 \mathrm{~mm}$ ) of flaky plastic rather than natural fine aggregate investigated by Saikia and De Brito [15] and the results obtained also show that increase in size of flaky plastic particle reduced the compressive strength. However, the compressive strength obtained at $5 \%$ and $3 \mathrm{~mm}$ flaky plastic was not significantly 


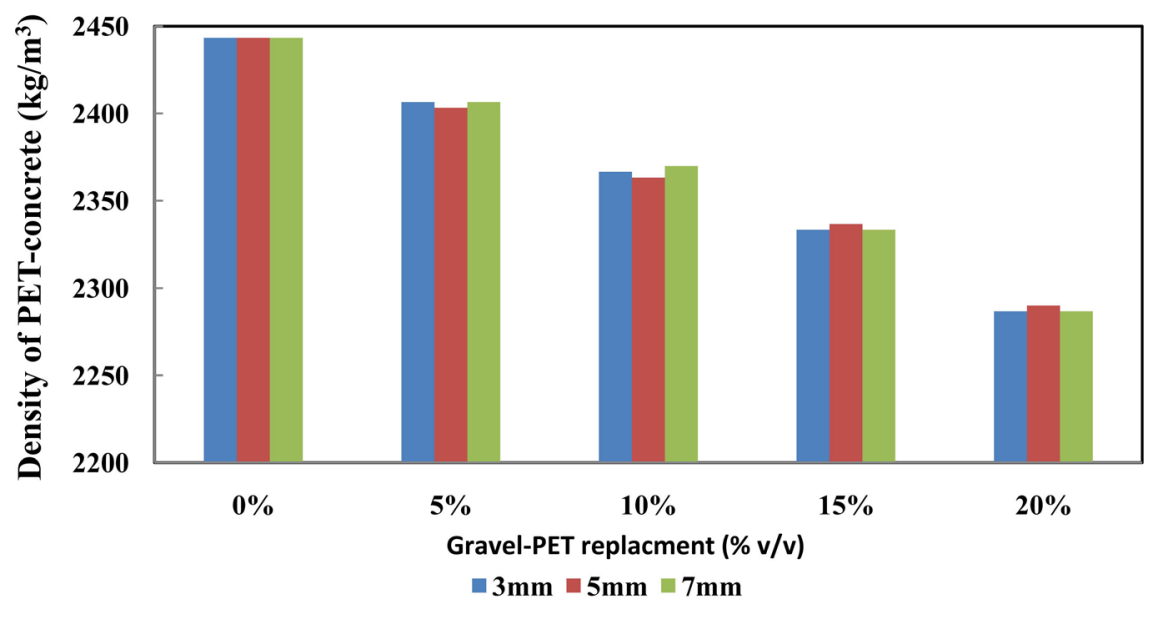

Figure 6. Change in density of cube specimens with different gravel PET replacement. Particle size: 3 - $7 \mathrm{~mm}$; volume of PET added: 0\% - 20\% (v/v).

different from the compressive strength of the concrete without PET $(p>0.05)$ while others indicated a significant difference from the concrete without PET ( $\mathrm{p}$ $<0.05)$. This suggests that the loss in compressive strength can be minimised at small plastic particle size and low percentage replacement (i.e. $5 \%$ and $3 \mathrm{~mm}$ flaky plastic).

\subsection{Effect of Plastic Size and Volume on PET-Concrete Density}

Figure 6 shows that increase in percentage PET from $0 \%$ to $20 \%$ as partial replacement of coarse aggregate (gravel) in the concrete decreased the density of the PET-concrete mix. This result conforms with decrease in density as fine aggregate (sand) in concrete replaced by the plastic bag waste (PBW) increased from $10 \%$ to $40 \%$ [29]. The resulting density decrease was attributed to induced voids created by the plastic waste causing greater volume than the concrete without plastic; hence reduced density [16] [17] [18] [19]. However, change in PET particle size at a fixed partial replacement has no significant effect on the density of PET-concrete mix. This could be explained by the fact that plastic is compressible; hence plastic of the same thickness, type, and percentage replacement can be compressed to the same volume regardless of different particle size when subjected to the same force.

\section{Conclusions}

From the results of this study the following conclusions were reached:

1) The compressive strength of the flaky PET-concrete reduces as the volume of gravel replaced by flaky PET increases from $5 \%-20 \% \mathrm{v} / \mathrm{v}$ gravel.

2) Increase in particle size ( $3-7 \mathrm{~mm})$ of flaky PET decreases the compressive strength of the PET-concrete mix.

3) Increase in volume of gravel replaced by flaky PET (5\% - 20\% v/v gravel) moderately decreases the density of the resulting PET-concrete mix but change in flaky PET particle size shows no significant effect on the density. 


\section{Conflicts of Interest}

The authors declare no conflicts of interest regarding the publication of this paper.

\section{References}

[1] Suganthy, P., Chandrasekar, D. and Kumar, S.P.K. (2013) Utilization of Pulverized Plastic in Cement Concrete as Fine Aggregate. International Journal of Research in Engineering and Technology, 2, 1015-1018.

[2] Williams, E.A. and Williams, P.T. (1997) Analysis of Products Derived from the Fast Pyrolysis of Plastic Waste. Journal of Analytical and Applied Pyrolysis, 40, 347-363. https://doi.org/10.1016/S0165-2370(97)00048-X

[3] Zhao, R., Torley, P. and Halley, P.J. (2008) Emerging Biodegradable Materials: Starch and Protein-Based Bio-Nanocomposites. Journal of Materials Science, 43, 3058-3071. https://doi.org/10.1007/s10853-007-2434-8

[4] Saikia, N. and De Brito, J. (2012) Use of Plastic Waste as Aggregate in Cement Mortar and Concrete Preparation: A Review. Construction and Building Materials, 34, 385-401. https://doi.org/10.1016/j.conbuildmat.2012.02.066

[5] Jibrael, M.A. and Peter, F. (2016) Strength and Behaviour of Concrete Contains Waste Plastic. Journal of Ecosystem and Ecography, 6, 186. https://doi.org/10.4172/2157-7625.1000186

[6] Merbouh, M., Glaoui, B., Mazouz, A. and Belhachemi, M. (2014) Use the Plastic Bag Waste in Cement Concrete. Waste Management Symposium, İstanbul, 28-30 April 2014, 1-6.

[7] Malak, K.R. (2015) Use of Waste Plastic in Concrete Mixture as Aggregate Replacement. International Journal of Education and Information Technologies, 3, 115-118.

[8] Sadiq, M.M. and Khattak, M.R. (2015) Literature Review on Different Plastic Waste Materials use in Concrete. Journal of Emerging Technologies and Innovative Research, 2, 1800-1803.

[9] BS EN 197-1 (2011) Cement Part 1: Composition, Specifications and Conformity Criteria for Common Cements. British Standard Institute, London.

[10] BS EN 12620:2002+A1 (2008) Aggregates for Concrete. British Standard Institute, London.

[11] BS 8500-2 (2015) Specification for Constituent Materials and Concrete. British Standard Institute, London.

[12] ASTM C143/C143M-15a (2015) Standard Test Method for Slump of Hydraulic-Cement Concrete. ASTM International, West Conshohocken.

[13] BS EN 12390-4 (2002) Testing Hardened Concrete: Compressive Strength of Test Specimens.

[14] Ismail, Z.Z. and Al-Hashmi, E.A. (2008) Use of Waste Plastic in Concrete Mixture as Aggregate Replacement. Waste Management, 28, 2041-2047. https://doi.org/10.1016/j.wasman.2007.08.023

[15] Saikia, N. and De Brito, J. (2014) Mechanical Properties and Abrasion Behaviour of Concrete Containing Shredded PET Bottle Waste as a Partial Substitution of Natural Aggregate. Construction and Building Materials, 52, 236-244. https://doi.org/10.1016/j.conbuildmat.2013.11.049

[16] Siddique, R., Khatib, J. and Kaur, I. (2008) Use of Recycled Plastic in Concrete: A 
Review. Waste Manage, 28, 1835-1852. https://doi.org/10.1016/j.wasman.2007.09.011

[17] Sikalidis, C.A., Zabaniotou, A.A. and Famellos, S.P. (2002) Utilization of Municipal Solid Wastes for Mortar Production. Resources, Conservation and Recycling, 36, 155-167. https://doi.org/10.1016/S0921-3449(02)00018-6

[18] Ferreira, L., Brito, J.D. and Saikia, N. (2012) Influence of Curing Conditions on Mechanical Performance of Concrete Containing Recycled Plastic Aggregate. Construction and Building Materials, 36, 196-204. https://doi.org/10.1016/j.conbuildmat.2012.02.098

[19] Avila, A.F. and Duarte, M.V. (2003) A Mechanical Analysis on Recycled PET/HDPE Composites. Polymer Degradation and Stability, 80, 373-382. https://doi.org/10.1016/S0141-3910(03)00025-9

[20] Silva, R.V., De Brito, J. and Nabajyoti, S. (2013) Influence of Curing Conditions on the Durability-Related Performance of Concrete Made with Selected Plastic Waste Aggregates. Cement and Concrete Composites, 35, 23-31. https://doi.org/10.1016/j.cemconcomp.2012.08.017

[21] Usman, M., Javaid, A. and Panchal, S. (2015) Feasibility of Waste Polythene Bags in Concrete. International Journal of Engineering Trends and Technology, 23, 317-319. https://doi.org/10.14445/22315381/IJETT-V23P259

[22] Ramadevi, K. and Manju, R. (2012) Experimental Investigation on the Properties of Concrete with Plastic PET Fibres as Fine Aggregates. International Journal of Emerging Technology and Advanced Engineering, 2, 42-46.

[23] Frigione, M. (2010) Recycling of PET Bottles as Fine Aggregate in Concrete. Waste Management, 30, 1101-1106. https://doi.org/10.1016/j.wasman.2010.01.030

[24] Albano, C., Camacho, N., Hendez, M., Matheus, A. and Gutierrez, A. (2009) Influence of Content and Particle Size of Waste PET Bottles on Concrete Behaviour at Different Water/Cement Ratio. Waste Management, 29, 2707-2716. https://doi.org/10.1016/j.wasman.2009.05.007

[25] Ramesh, R.L., Asharani, K.M., Dhiraj, K.V.C., Pruthvi, S.D.S. and Sahana, R. (2012) Recycled Plastics Used as Coarse Aggregate for Constructional Concrete. SJB Institute of Technology, Bangalore.

[26] Patil, P.S., Mali, J.R., Tapkire, G.V. and Kumavat, H.R. (2014) Innovative Techniques of Waste Plastic Used in Concrete Mixture. International Journal of Research in Engineering and Technology, 3, 29-32.

https://doi.org/10.15623/ijret.2014.0321008

[27] Batayneh, M., Marie, I. and Asi, I. (2007). Use of Selected Waste Materials in Concrete Mixes. Waste Management, 27, 1870-1876. https://doi.org/10.1016/j.wasman.2006.07.026

[28] Choi, Y., Moon, D., kim, Y. and Lachemi, M. (2005). Characteristics of Mortar and Concrete Containing Fine Aggregate Manufactured from Recycled Waste PET Bottles. Construction and Building Material, 23, 2829-2835.

https://doi.org/10.1016/j.conbuildmat.2009.02.036

[29] Ghernouti, Y., et al. (2011) Use of Recycled Plastic Bag Waste in the Concrete. Journal of International Scientific Publications. Materials, Methods and Technologies, 8, 480-487. 